\title{
New method, same curriculum - Taking a step back to reflect on 'doing' comprehensive sexuality education in the 21st century
}

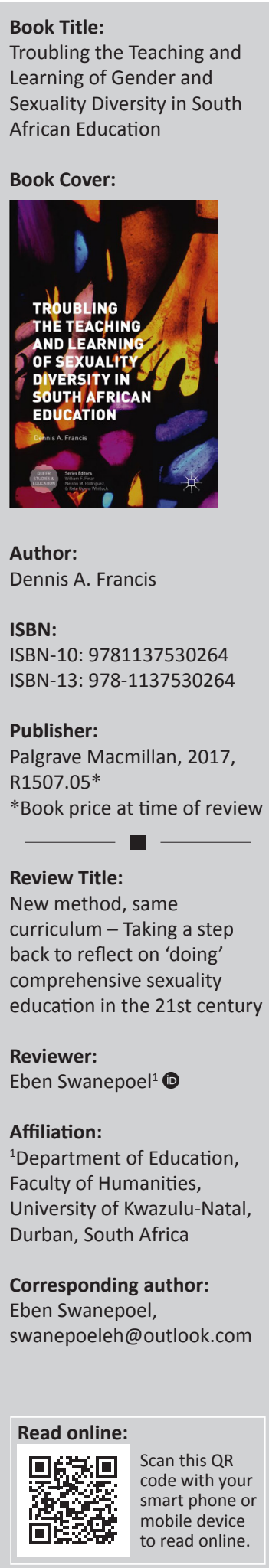

A year prior to the writing of this book review, in 2019, the introduction of a revised and more structured lesson plan framework for comprehensive sexuality education (CSE) witnessed heated public debate, especially amongst parents on social media, as promoting perverse and anti-Christian content towards sexuality and diversity in South African schools. Central to this public scrutiny is the subject Life Orientation, the mandatory subject implemented in post-apartheid South Africa to constitutionally align values of harmony, acceptance and reconciliation amongst learners as a core initiative to rectify imbalances of violence and intolerance in post-apartheid South Africa. The question however remains as to whether public opinion is uncritically focused on curriculum content without systemically scrutinising the macro-system of oppression imbedded in incongruent teachings and curriculum coverage set out in the past already. At the front, South Africa is currently challenged by increased gender violence, with the human immunodeficiency virus (HIV) and acquired immunodeficiency syndrome (AIDS) pandemic and teenage pregnancies at a rapid rise each year.

My review of the book by D. Francis, entitled Troubling the Teaching and Learning of Gender and Sexuality Diversity in South African Education, is aimed at entering the discourse about the changing method of teaching about gender and sexuality in schools as not being based on a new curriculum, but instead reiterating the need for stakeholders to re-learn and reflect on the dynamic landscape of teacher education to align with standards already upheld through curriculum and constitutional ideals often construed in classrooms because of silencing textbook and curriculum knowledge. Specifically, contextualising the socio-historical backdrop of silence and bias-based teaching of gender and sexuality, Francis highlights the systemic influence of South African school systems deconstructing critical topics of sexuality and gender diversity, and in turn perpetuating discord and intolerance through previous teaching methods rooted in silence, bias and oppressive views to the detriment of shaping pro-active learners in society. By not troubling the self in relation to the macro-system influences of oppression, we are in danger of perpetuating gender violence and discrimination not only through curriculum and policy alone, but also through ways of 'doing' which are left unchallenged on part of teachers and stakeholders who interpret curriculum content inconsistently, evoking emotive responses (such as those evident through current societal reactions to the structured CSE curriculum layout), bias and silence in classrooms surrounding gender and sexual diversity.

I reflect on the work of Francis as a critical and systemic exploration of the lived experiences of South African youth and teachers in schools to challenge public perceptions about gender and sexual identity, acceptance and tolerance. The relevance of Francis' book, 4 years after the first publication, shows the longitudinal validity of dismantling oppressive perceptions that root South African education and public bias in closed-systems of cultural knowledge, unyielding to re-learn values of peace and reconciliation across diverse cultural boundaries, such as identity diversity, religion and culture. At its core, the book recognises the systemic influences of heteronormativity and homophobia within the South African school contexts as parallel to oppressive societal values rooted in stagnant socio-historical knowledge systems of racism, sexism and homophobia. These facets of oppression are often construed by a decontextualised understanding of culture as dynamic, thus rooting knowledge in teachings which are detrimental to learner needs of the 21st century, especially with new generational underpinnings of knowledge systems constantly developing (DePalma \& Francis 2014). Focussing not only on curriculum and policy challenges towards anti-oppressive education, the discourse Francis

How to cite this book review: Swanepoel, E., 2020, 'New method, same curriculum - Taking a step back to reflect on 'doing' comprehensive sexuality education in the 21st century', The Journal for Transdisciplinary Research in Southern Africa 16(1), a803. https:// doi.org/10.4102/td.v16i1.803

Copyright: @ 2020. The Authors. Licensee: AOSIS. This work is licensed under the Creative Commons Attribution License. 
enters encompasses the overarching constitutional values at the fore to elucidate challenges faced by teachers and researchers during the teaching and researching of sexuality and gender diversity against the backdrop of anti-apartheid South Africa.

The content areas of teaching learners about sexual orientation and diversity have been central to arguments that the curriculum is anti-Christian, verging on 'pornographic' material, and promoting familial structures beyond the normative heterosexual family structure as being acceptable. These discourses however are rooted in the exact oppressive values that Life Orientation and CSE aim to trouble, deconstruct and synthesise into the constitutional ideals of peace and reconciliation amongst multicultural citizens bringing forth the practice and spirit of Ubuntu. It is not that a new knowledge is being implemented, but rather a re-negotiated way in which the knowledge is conveyed at grassroots level by teachers in the classroom. The book Troubling the Teaching and Learning of Gender and Sexuality Diversity in South African Education challenges these misconceptions beyond the vanity of a structured curriculum towards understanding the larger role of educators in ultimately evoking a voice to the set curriculum, and subsequently in dismantling oppressive attitudes at macro-societal level. The book situates teachers as fundamental agents of change in the process of restorative practice within societal harmony through evoking a macro-level emotional underpinning about the oppressive aftermath and experiences of lesbian, gay or bisexual (LGB) youth in South African schools. Emotions, as Reygan and Francis (2015) articulate, are central to social justice, with teachers enabling socially unjust teachings through negative perceptions and silence surrounding topics of diversity and sexuality in the classroom. Francis challenges the reader to enter a reflective narrative with the self, contextualising teaching about gender and sexuality diversity as core to situating a curriculum on messages of collaborative values promoting love, intimacy and harmony as core principles to a harmonious multicultural society.

Francis, in retrospect, challenges all stakeholders of antioppressive education to sit back and reflect, both on the self and on ways of 'doing' beyond theory and by extension not at merely the face value of curriculum alone. Instead, we are situated as observers to the macro-level influence of school systems where ways of doing have been unyielding to decades of curriculum change and development aimed at preparing learners to enter the globalised vocational market with values of respect for diversity and culture. Specifically, Troubling the Teaching and Learning of Gender and Sexuality
Diversity in South African Education troubles the emotive preconceived notions and contextual understanding of sexuality and gender at individual level as parallel to classroom practice ideals in an effort to curb silence in not only classrooms but also society at large. This book holds strong merit for teacher induction, current teachers teaching Life Orientation as well as stakeholders such as parents to better negotiate an understanding of the value of a layered, structured and pre-set curriculum as part of the process towards social justice and breaking the silence surrounding issues of gender and sexual violence, teenage pregnancies and HIV and AIDS in South African schools.

Francis draws on an inclusive sample of 33 Life Orientation teachers in the Free State province of South Africa, of which five teachers were identified as LGB. The sample spans across farm schools, rural and urban areas. The second sample consists of 19 LGB learners. Of note is that the wider spectrum of inclusive identities such as transgender and intersex are not silenced or ignored, but that the data dissemination and subsequent reporting were informed by the narratives of the participants who were active agents in shaping their perceived identities during the data collection process. While located specifically in the Free State, the book is one of the first committed books based on queer education of this depth in South Africa.

While data centre on teachers and learners, Francis draws on all aspects of 'doing' teaching and research towards inclusive sexuality and gender diversity in schools, spanning to the intersections of how researchers enter communities with preconceived notions of inclusivity, deficit-centred frameworks and invisibility towards learners of diverse sexualities and genders. With this refection, all stakeholders become accountable to re-negotiate ways of doing theory and practice, and to challange knowledge which is not on par with socially just ideals. The reader is challenged to return to grassroots level understanding regarding how we 'do' research and teaching in the realm of sexuality and diversity. It is argued that teaching and research is a futile endeavour if not done from the vantage point of restoring agency to learners who are, in fact, often more knowledgeable about their own identities than adults may believe, if we only take the time to listen.

\section{References}

DePalma, R. \& Francis, D., 2014, 'Silence, nostalgia, violence, poverty...: What does "culture" mean for South African sexuality educators?', Culture, Health \& Sexuality 16(5), 547-561. https://doi.org/10.1080/13691058.2014.891050

Reygan, F. \& Francis, D., 2015, 'Emotions and pedagogies of discomfort: Teachers' responses to sexual and gender diversity in the Free State, South Africa', Education as Change 19(1), 101-119. https://doi.org/10.1080/16823206.2014.943259 